Yunzhou Du, Bing Ren, Zhongwei Chen, Yuli Zhang

\title{
Proactiveness, Legitimation via ISO Certification and the Growth of SMEs in China
}

\author{
(C) Higher Education Press and Springer-Verlag 2010
}

\begin{abstract}
According to the literature on entrepreneurial orientation (EO), proactive firms are more likely to achieve first-mover advantage and higher performance. The neoinstitutionalism, however, suggests that enterprises with more legitimacy will acquire more growth opportunities. Usually, the first mover might face more legitimacy obstacles. To date, there has been little research on how proactive firms cope with legitimacy constraints and achieve firm growth. Integrating the legitimacy perspective and the EO literature, this research examines the roles of ISO certification as a strategy for seeking legitimacy of small and medium-sized enterprises (SMEs) in emerging economies, and the relationship between proactiveness and firm performance. In particular, it hypothesizes that ISO certification has a mediating effect on the relationship between proactiveness and firm growth. We test the hypothesis using a sample of 632 firms collected from a nationwide survey on SMEs conducted by the Chinese SME Association. The results reveal that ISO certification partially
\end{abstract}

Translated from Guanli Shijie 管理世界 (Management World), 2008, (12): 126-138

Yunzhou Du ( $\triangle)$

School of Business, Nankai University, Tianjin 300071, China

School of Management, Anhui University of Finance \& Economics, Bengbu 233030, China

E-mail: duyunzhou_2000@sina.com

Bing Ren

School of Business, Nankai University, Tianjin 300071, China

E-mail: renbing@nankai.edu.cn

Zhongwei Chen

School of Management, Anhui University of Finance \& Economics, Bengbu 233030, China

E-mail: czwancai@sohu.com

Yuli Zhang

School of Business, Nankai University, Tianjin 300071, China

E-mail: ylzhang@nankai.edu.cn 
mediates the relationship between proactiveness and firm growth, suggesting that proactive firms tend to use legitimation via ISO certification to enhance firm growth. Our paper contributes to the literature by shedding light on the important relationship between seeking legitimacy, entrepreneurial orientation and firm growth in SMEs in an emerging economy.

Keywords proactiveness, legitimation, institution theory, ISO certification, firm growth

\section{Introduction}

Since companies with high proactiveness may gain first-mover advantage, the extant literature argues that proactive SMEs are more likely to gain better performance (Miller and Friesen, 1983; Lumpkin and Dess, 1996). However, Lumpkin and Dess (1996) pointed out that the relationship between entrepreneurial orientation (EO) and firm growth will adjust according to the elements of environments and organizations. Following this thought, many of the subsequent studies have focused on the contingent effect of EO on firm performance. They revealed that the relationship between EO and firm performance is affected by the fitness of EO to organizational environment, structure, firm strategies (Lumpkin and Dess, 1996; Wiklund and Shepherd, 2003), and social capital (Stam and Elfring, 2008). Some researchers also found interactive effects between market orientation (MO) and EO (Li, Zhao, Tan and Liu, 2008).

According to institutional theory, companies with a high degree of proactiveness might face more constraints of legitimacy. For example, the first enterprise that enters into a new market might face a lower degree of approval from the stakeholders such as customers, and encounter legitimate obstacles of cognition (Lieberman and Montgomery, 1988). Therefore, enterprises with a high degree of proactiveness do not always gain first-mover advantage (Teece, 1986; Lieberman and Montgomery, 1988; Haunschild and Miner, 1997).

Hargadon and Douglas (2001) suggested that a large number of first-moving actors have experienced failure when they introduced new products into the market. Boiral (2003) pointed out that ISO9000 quality system certification, which has already been popularized rapidly all over the world, is an important method for enterprises to gain legitimacy (Boiral, 2003; Zimmerman and Zeitz, 2002). According to the neoinstitutionalism, under the condition of information asymmetry, people often lack the necessary knowledge to judge the value and the reliability of newly introduced products. Therefore, certification of the third party provides the basis for customers and other stakeholders to make the right 
judgments (Scott, 1995; Boiral, 2003). Still, there is a big research gap in EO literature: as summarized by Lumpkin and Dess (1996) prior studies on EO focusing on the contingency relationship between EO and firm performance (Lumpkin and Dess, 1996; Dess and Lumpkin, 2005), however, few scholars have suggested that EO has indirect effect on profitability (Baker and Sinkula, 2009). Moreover, previous studies have neglected the process that how EO transforms into firm performance. Existing studies suggest that gaining ISO can help proactive enterprises to obtain legitimacy and growth. However, empirical research is especially lacking on the effect of ISO certification on the link between EO and performance. To help fill this gap, this paper focuses on the following research questions: how do proactive enterprises seek firm growth, and what role does ISO certification play during the growth process? To answer the above questions, this paper constructs a mediating model, which hypothesizes that ISO certification as a strategy of legitimation plays the mediating role in the relationship between proactiveness and firm growth.

The paper is organized as follows: Section 2 presents the theoretical background, where we review briefly the EO theory and the legitimacy perspective. Section 3 is focused on hypotheses development. Section 4 describes the research method, including sampling and data collection, measurement, and factor analysis. Section 5 presents the analysis and results. The last section offers the discussion and conclusions.

\section{Theoretical Background}

\subsection{Entrepreneurial Orientation}

During the late 1970s and the early 1980s, when strategy scholars shifted their attention from strategic content to strategic process (Bourgeois, 1980), EO was identified as an important construct. EO is the decision-making process and practice that produce the new entry (Lumpkin and Dess, 1996; Dess and Lumpkin, 2005). For the construct of EO, Miller (1983), Covin and Slevin (1989) proposed three dimensions: innovativeness, risk taking and proactiveness (Miller and Friesen, 1983; Covin and Slevin, 1989). Later, Lumpkin and Dess (1996; 2005) identified five dimensions, namely autonomy, innovativeness, risk taking, proactiveness, and competitive aggressiveness (Lumpkin and Dess, 1996; Dess and Lumpkin, 2005). Proactiveness means that a company is the first one to introduce a product or service into the market with the quickest innovation (Miller and Friesen, 1983; Lumpkin and Dess, 1996; 2005).

Proactiveness has received special attention in the EO research field. Lumpkin and Dess (1996) pointed out that instead of responding to the competitors passively, proactive enterprises are much more active in seizing market 
opportunities, looking for the leading position in the market, and taking actions to change the environment.

Proactiveness has been regarded as having a positive effect on performance (Lumpkin and Dess, 1996; Baker and Sinkula, 2009). However, as mentioned earlier, the extant research has paid little attention to how proactiveness is transformed into high performance. Some researchers argued that first movers may encounter obstacles of customers' cognition (Lieberman and Montgomery, 1988) and proactiveness' effect on performance is indirect (Baker and Sinkula, 2009).

\subsection{The Legitimacy Perspective}

Organizational legitimacy is a core concept in institutionalism, which derives from Weber's (1958) study on bureaucratic organizations. Weber believed that rules and standardized control of bureaucracy improve an organization's efficiency and institutionalize an "iron cage" of capitalism, which becomes the norm and constraints of human behaviors. According to Weber, the organizational legitimacy will be gained under the condition that organizations adopt actions by conforming to the coercive rules and structures that organizations confront. Later institutionalist scholars such as Parsons (1960) expanded the meaning of organizational legitimacy, who believed that organizational legitimacy is the conformance between an organization's value and its social context.

After Weber and Parsons, the neoinstitutionalism emphasizing social cognition system holds that under the condition of the bounded rationality and the uncertainty of the environment, it is difficult for constituents themselves to judge the organizational values and acceptability. Thus, constituents judge organizational legitimacy according to the organizations' conformance to the existing social system (including the regulations, norms and social cognitions) (Ruef and Scott, 1998; Tornikoski and Newbert, 2007). In terms of why the cognition is important, it is argued that the social structure defines the proper roles and rules of action, and cognition is the basis of social structure (Scott, 1995; Zimmerman and Zeitz, 2002).

The neoinstitutionalism also argues that people will make a general perception and assumption on the appropriateness, properness and desirableness of organization activity, which constitutes the degree of legitimacy (Suchman, 1995). Legitimating is the process that organizations seek to improve constituents' perception of organizational legitimacy (Maurer, 1971). Generally speaking, organizations gain legitimacy by reaching conformance to widely accepted social system (regulations, norms and cognitions) (Ruef and Scott, 1998; Dowling and Pfeffer, 1975; DiMaggio and Powell, 1991; Scott, 1995). Early 
institutionalists suggested that organization gain legitimacy by passively conforming to the generally accepted regulations, norms and ceremonies (DiMaggio and Powell. Most present institutionalists believe that organizations should take legitimating actions actively and focus more on the key stakeholders' perception since these stakeholders have crucial influence on organizations' reputation and survival (Pfeffer and Salancik, 1978; Zimmerman and Zeitz, 2002).

In a word, the legitimacy perspective suggests that entrepreneurs need to take actions of legitimation by conforming to the enterprise's identity and role defined by social system, and actively respond to the legitimate requirements of the primary stakeholders. Institutionalists argue that ISO9000 is to respond to the institutionalized expectation of stakeholders. Enterprises adopt ISO certification ceremonially or symbolically in order to gain legitimacy. However, within the enterprises, ISO certification is not really used to improve the quality of products or services (Boiral, 2003; Meyer and Rowan, 1977).

Supporting the institutionalists' argument, other scholars have suggested that enterprises can enhance legitimacy by taking symbolic actions which are not really put into practice. For example, Zott and Huy (2007) pointed out that entrepreneurs enhance legitimacy and facilitate access to resources by taking symbolic actions, such as conveying the reliability of the entrepreneurs, the organizational achievements and the relationship with certain high status stakeholders.

\section{Hypotheses}

\subsection{Proactiveness and Firm Growth}

Starting from the early 1980 s, studies on the entrepreneurship process began to focus on the relationship between EO and firm performance. For example, Miller and Friesen (1983) tested the influence of EO on firm performance and found that EO is positively related to firm growth. Following Miller and Friesen (1983), Covin and Slevin (1989) further compared the relationship between EO and firm performance in a hostile environment and a benign environment, and found that relative to the benign environment, the positive effect of EO on firm growth is much more remarkable in the hostile environment.

The studies on the relationship between EO and firm performance (e.g., Miller and Friesen, 1983; Covin and Slevin, 1989; Lumpkin and Dess, 1996) have laid important foundations for the EO research field. Moreover, these previous studies not only explored the main effect of EO on firm growth, but also tested the contingency effect of the EO on performance (Stam and Elfring, 2008).

Lieberman and Montgomery (1988) pointed out that enterprises that firstly 
enter a field are more likely to seize proactive opportunity and gain first-mover advantage, such as taking the lead of establishing the cognitive position of brands, and receiving much more attention and superior profit. Proactive firms put greater emphasis on the advancement and predictability of their actions, and the leading position in the product or service market. As the first movers, they can obtain high profit by exploiting the asymmetries of the market and establishing the brand cognition advantage (Lumpkin and Dess, 1996; Dess and Lumpkin, 2005). Taken together, we developed the following hypothesis:

H1 Proactiveness is positively related to the growth performance of SMEs.

\subsection{Legitimacy and Firm Growth}

The legitimacy perspective holds that compared to the internal management problems, lacking of external legitimacy may be the main reason for the liability of newness and the high organizational mortality of new ventures (Stinchcombe, 1965; Singh, Tucker and House, 1986). Hargadon and Douglas (2001) also argued that a robust legitimation strategy is even more important for new ventures who introduce an innovative product in their initial period of entrepreneurship (Hargadon and Douglas, 2001).

Gaining legitimacy is helpful for overcoming the liability of newness (Stinchcombe, 1965) and improving the company's credibility and reliability (Tornikoski and Newbert, 2007; Shepherd and Zacharkis, 2003). Legitimacy promotes the resources acquisition and growth of new ventures (Zott and Huy, 2007), whose function is not inferior to capital, human recourse, technology and so on (Zimmerman and Zeitz, 2002). Under the constraint of institutional legitimacy, the growth of new ventures depends on the fact that to what extent the entrepreneurs give enough emphasis on legitimacy seeking and taking the corresponding legitimation actions (Delmar and Shane, 2004; Zimmerman and Zeitz, 2002).

The existing research on legitimation finds that certification is an important approach of improving organizational legitimacy (Zimmerman and Zeitz, 2002). SMEs' obtaining ISO quality certification increases the possibility of commercial cooperation with distributors, suppliers, and competitors, and increases the chances of entering international market (Boiral, 2003). As the third party institution, the ISO certification can improve organizational legitimacy more effectively and promote their growth (Stuart, Hoang and Hybels, 1999).

ISO9000 certification has already been applied widely in practice. Boiral (2003) pointed out that there are three reasons behind enterprises' gaining ISO certification. First, as a global united standard, ISO certification facilitates the internationalization of SMEs by decreasing trade barriers among countries or 
regions (Boiral, 2003). Second, under the complex commercial environment with information asymmetry, the ISO certification systems have become a tool for the companies' stakeholders to judge the reliability and credibility of the enterprise quality, and to decide whether to cooperate with it (Boiral, 2003). Third, ISO certification has become the means for enterprises to strengthen organizational image and enhance competitiveness (Boiral, 2003).

According to the legitimacy perspective, enterprises' adoption of ISO certification is not for quality improvement, but for the acquisition of legitimacy and performance improvement (Zott and Huy, 2007). Therefore, we assume that there is no significant difference on the quality guarantee between firms having obtained the ISO certification and those have not, and there shall exist significant differences in terms of growth performance between the above two groups.

According to the above discussion, we develop the following hypotheses.

H2a Legitimation via ISO certification is positively related to the growth performance in SMEs.

H2b There is no significant difference on the quality guarantee system between the SMEs with ISO certification and the SMEs without.

\subsection{The Mediating Role of Legitimation via ISO Certification}

Compared to companies that already operate in the existing field, proactive enterprises encounter much more obstacles in legitimacy. Because customers tend to have low cognition about new products' certainty and reliability (Lieberman and Montgomery, 1988), first-movers often face the liability of newness (Stinchcombe, 1965) accompanying the new product or service development. Therefore, enterprises with high proactiveness face a paradox: on one hand, they might gain first-mover advantage; on the other hand, they might face problems such as the low cognitive legitimacy.

Therefore, first-mover advantage might be counteracted by first-mover disadvantage (Lieberman and Montgomery, 1988), since the existing customers might choose to remain loyal to the existing products and brands rationally when facing the uncertainty of new products' quality (Lieberman and Montgomery, 1988). Researchers have also found that if later-movers establish duplicating ability quickly on the basis of imitation and if first-movers do not establish the needed legitimacy, later-movers will seriously challenge the first-movers (Haunschild and Miner, 1997).

When existing organizations are entering a new area of activity, they need to extend organizational legitimacy (Ashforth and Gibbs, 1990). Hargadon and Douglas (2001) found that entrepreneurs face strong constraints from the existing institutions, such as lack of customers' cognition, when they firstly introduce 
innovative products into market. Successful enterprises must consider how to make use of the existing cognitive system to enhance legitimacy and legitimize new products robustly when they are introduced into the market (Hargadon and Douglas, 2001). ${ }^{1}$

Few researches have suggested the effect of proactiveness on performance is indirect (Baker and Sinkula, 2009). Furthermore, proactive firms face legitimacy problem. They need to adopt legitimation measures to improve legitimacy and grasp the fleeting entrepreneurial opportunities. During this process, legitimation plays a mediating role between the proactiveness and firm growth. We therefore develop the following hypothesis:

H3 Legitimation via ISO certification plays a mediating role in the relationship between proactiveness and SMEs' performance.

\section{Methods}

\subsection{Sampling and Data Collection}

China is selected as the sampling context because it is one of the most important emerging economies due to her wide spread of new venture creations and SMEs in the economy. In October 2007, the Chinese SMEs Association worked with the Entrepreneurial Management Research Center at Nankai University to design the questionnaire "Chinese SMEs' Status and Policy Study." The variables studied in this paper are organically embedded in this survey, and thus we collected and examined data from this questionnaire. The subject of the investigation is SMEs across the country, and the respondents were top managers or founders of these SMEs. The questionnaires were sent to sampled firms by the SMEs Association in November, 2007. Due to the fact that the survey was conducted by the Chinese SMEs Association, a government agency at the national level, a total of 639 valid copies were returned, with a satisfactory response rate of $80 \%$.

The definition of SMEs varies in China. The newest one is jointly given by the National Development and Reform Commission and the Ministry of Finance via the Notice on SMEs' Standard Provisional Regulation on February 19 ${ }^{\text {th }}, 2003$. According to the provisional regulation, as a SME, the number of employees shall satisfy the following conditions: The number of employees in an industrial

${ }^{1}$ For example, under the social background that people had used gaslight for many years, Edison used the familiar language, standard and certification in the existing social system to convey the knowledge and advantage of the new products (electric light) so that new products and the existing products (gaslight) are connected, thus the new products' perceived legitimacy is extended successfully (Hargadon and Douglas, 2001). 
firm should be no more than 2 000; in construction, transportation and post industries, there should be no more than 3000 ; that in wholesale and retail industries, there should be no more than 500. According to this definition, we eliminated 7 cases that do not satisfy the above conditions, thus the final number of valid samples was 632 .

Among the 503 sampled SMEs that answered the questions in the questionnaire concerning the ISO certification acquisition, $56.1 \%(282)$ have the certification, and $43.9 \%$ (221) do not (including those that did not apply for and those that are still applying for).

\subsection{Measures}

Firm growth performance. Three indicators have been adopted in extant literature to measure a firm's growth performance: sales growth rate, market share and pre-tax profit growth rate (Miller and Friesen, 1983; Baum, Locke and Smith 2001). In this paper, we measure the growth performance by asking the respondents three separate questions: Please evaluate your company's advantages over your main competitors in terms of average sales growth rate (or in market share or pre-tax profit growth rate) and select a corresponding number in below (a five-points Likert scale is used to measure the competitiveness of the company with 1 indicating the lowest level and 5 the highest).

Quality guarantee system. This is measured by two items: "normative management" and "stable quality," each of which is asked by a five-point Likert scale with 1 indicating the lowest level of normative management or stable quality and 5 indicating the highest.

Proactiveness. The measuring of proactiveness adopts the scale of Covin and Slevin (1989), which uses 9 items to measure three EO factors: proactiveness, innovativeness and risk-taking. Five-points Likert scales were used to measure each item with 1 indicating "don't agree at all" and 5 indicating "agree completely."

Legitimation via ISO certification. When measuring legitimacy, different approaches have been adopted, depending on different research objects. For example, Ruef and Scott (1998) examined the normative legitimacy in hospitals, in which whether the hospital is subordinate to or authorized unit by medical or surgical hospital is used to measure the normative legitimacy of technology, such as whether the hospital is one of the designated hospitals of the USA Blue Cross Insurance Company or a member of the USA Hospital Association to measure the normative legitimacy of management. Deephouse (1996) measured the public legitimacy by media's evaluation of commercial banks. Tornikoski and Newbert 
(2007) measured the legitimacy of new ventures' strategy by resource combination and networking.

ISO certification is an important tool for most enterprises to improve legitimacy (applied to different industries), and is also an important indicator for legitimacy which is emphasized by theoretical research (Zimmerman and Zeitz, 2002). Besides, the recognition and acceptance of stakeholders for ISO certification is relatively high. Since ISO certification is an independent third party's certification, the fact that whether the enterprise can pass it or not represents the enterprise' normative legitimacy to some extent, and also represents the judgment basis for stakeholders such as customers to perceive the organizational legitimacy. Therefore, this paper adopts ISO certification to measure legitimacy. We asked the respondents that whether their company passed ISO certification (passed $=1$, and 0 otherwise). According to the literature, the legitimacy level of those enterprises that have passed the ISO is higher.

Control variables. According to the existent study on EO, environmental contingency affects the relationship between EO and firm performance (Miller and Friesen, 1983; Covin and Slevin, 1989; Lumpkin and Dess, 1996). Therefore, we control environment factor in our study. In order to analyze the mediating function of legitimacy between proactiveness and EO, we also control the other two dimensions of EO - innovativeness and risk-taking. Environmental variables adopt the measuring scale of Miller and Friesen (1983) and Covin and Slevin (1989), which has six measuring items with each item represented by a five point Likert scale ranging from 1 (disagree completely) to 5 (agree completely).

At the same time, according to the firm growth theories such as lifecycle, this paper controls the influence of size, company's age, industry type on firm growth performance (Baum, Lock and Smith, 2001). Among them, size is measured by the number of employees in a sampled company. Company age is the time from the day when the company was established to the time when the questionnaire was filled. Business is divided into 8 types, including manufacturing; wholesale $\&$ retail, restaurants; transport, storage \& postal, construction, finance, insurance, education \& culture, real estate, and others. The company size and age is standardized by the $Z$ score.

Since each questionnaire often came from one respondent, our study may suffer the common method variance biases. This paper employs Harman's single factor test recommended by Podsakoff and Organ (1986) to measure the level of common method biases. From the exploratory factor analysis of all the unrotated variables, the percentage of variance explanation of the first factor is $14.39 \%$, which means there is no serious common method biases problem. 


\subsection{Factor Analysis, Reliability, and Validity Test}

To test the reliability and validity of each construct in the measure model, we carried out the exploratory factor analysis (EFA), construct validity test, correlation analysis and Cronbach's alpha test.

Exploratory factor analysis of proactiveness. This paper carried out EFA of the measuring scale of EO consisting of 9 items and 3 factors and developed by Covin and Slevin (1989), and Miller and Friesen (1983). As a result, 2 factors and 7 items are extracted ${ }^{2}$ with the above 632 sampled SMEs. Results show that the first four items more corresponds to Covin and Slevin's (1989) risk taking factor $^{3}$ and the later three corresponds to Covin and Slevin's (1989) 3-item scale of proactiveness. However, the risk-taking and innovativeness factors are not differentiated clearly, which is similar to Li's (2007) study. The reason might be that Covin and Slevin (1989) measured risk-taking by fearless debt and credit, while Chinese SMEs have limited financing channels and cannot achieve the operating goal of the company by debt and credit like those in the west. And Chinese culture is not so strongly supportive of innovation as west countries, so innovativeness and risk taking are not differentiated clearly in the Chinese context. We hence named the first four items as innovativeness and risk taking.

The Kaiser-Meyer-Olkin Measure of Sampling Adequacy (MSA) on the 7 items is 0.834. The Bartlett's Test of Sphericity's Approx. Chi-Square is 1103.381 ( $d f$ is $21, p$ is 0.000 ), which means it is very suitable for EFA. The items of the two factors are notably correlated at the 0.01 level. According to the principal component analysis and varimax, these two factors account for $68 \%$ of the total variance. The Cronbach's alpha value of proactiveness factor is 0.747 and the Cronbach's alpha value of innovativeness and risk taking is 0.774 . These results suggest that the reliability of the two scales is statistically satisfactory (Cronbach's alpha with more than 0.5 is acceptable and more than 0.7 is fine). Table 1 provides the EFA results and factor loading of two EO factor: the innovativeness and risk taking and the proactiveness.

EFA of firm growth performance. According to the three growth indicators (sales growth rate, market share and pre-tax profit growth rate) recommended by Miller and Friesen (1983), and Baum, Locke and Smith (2001), we conducted the EFA and extracted a growth performance indicator. The KMO test of MSA' value is 0.731 , the Bartlett's Test of Sphericity's Approx. Chi-Square is 653.424 ( $d f$ is $3, p$ is 0.000 ), which means it is suitable for factor extraction. Each item of factors is notably correlated on the level of 0.01. According to principal

${ }^{2}$ Other research has not extracted innovativeness factor in the Chinese context either.

${ }^{3}$ One item came from innovativeness scale. 
component analysis and varimax, the growth performance factor accounts for $78.52 \%$ of the total variance and the Cronbach's alpha value of growth performance is 0.863 , which means the reliability of this scale is fine. The factor loading of firm growth performance is shown in Table 2.

Table 1 EFA Result of Proactiveness

Factor 1 Factor 2

\section{Factor 1: Innovativeness and risk taking}

1. Most new products (service) are innovated to a great extent

2. The company tends to invest in the projects with high risk and high return

3. To reach the firm goal by taking daring, quick action

4. Tend to take daring active attitude to seize the potential opportunity when facing uncertain environment

\section{Factor 2: Proactiveness}

1. Facing competitors, the company often takes action first, and then competitors respond to your action

2. The company tends to be the "leader", taking the lead in introducing new products, management pattern, new technology or first entry into the market

3. Top managers keep a close watch on environmental change, lead off to seize opportunity, and take proactive action to respond to the change

Table 2 EFA Result for Growth Performance

\begin{tabular}{ll}
\hline & Factor 1 \\
\hline Factor 1: Growth & \\
1. Sales growth rate & 0.886 \\
2. Market share & 0.903 \\
3. Pre-tax profit growth rate & 0.869 \\
\hline
\end{tabular}

EFA of environment. Based on the environmental measuring scale of Miller (1983) and Covin and Slevin (1989), a measure scale with 4 items was extracted from 6 items by EFA measuring the environmental benignity. The MSA value is 0.720 by KMO test and the Bartlett's Test of Sphericity's Approx. Chi-Square is 305.738 ( $d f$ is $6, p$ is 0.000 ). The four items of the factor are notably correlated on the level of 0.01 . According to the principal component analysis and varimax, the environmental factor accounts for $52.358 \%$, of the total variance and the Cronbach's alpha value of this factor is 0.696 , which means the reliability of this scale is acceptable. Table 3 presents the loading of the environmental factor. 
Table 3 EFA Result of Environment

\begin{tabular}{lc}
\hline & Factor $\mathbf{1}$ \\
\hline Factor1: Environment & \\
1. Technology changes very quickly in the industry & 0.687 \\
2. Social service system is not perfect & 0.668 \\
3. Competition in the industry is excessive & 0.788 \\
4. The competition among similar competitors in the market is intense & 0.746 \\
\hline
\end{tabular}

Construct validity test. To test construct validity, as recommended by Aderson and Gerbing (1988), and Nadkarni and Narayanan (2007), we conducted confirmatory factor analysis of innovativeness and risk taking, proactiveness, growth performance, legitimacy and environment. Results show that the fitting degree of the data on these five variables is fine $\left(\chi^{2}=152.00, d f=85\right.$, RMSEA $=$ $0.049, \mathrm{NNFI}=0.96, \mathrm{NFI}=0.93, \mathrm{CFI}=0.97, \mathrm{GFI}=0.94)$. Besides, the related coefficients of the five factors are all less than 0.3 (indicating a weak correlation); amongst which, innovativeness and risk taking and legitimacy are uncorrelated $(r=0.06, p>0.1)$, which means the discriminate validity of the measuring scale is good. At the same time, the factor loading of the environmental factor reaches an acceptable level of 0.5 , and the factor loading of proactiveness, innovativeness and risk taking, and growth performance is between $0.6-0.85$, which is acceptable. Moreover, since each measure came from previously validated ones, their convergent validity is superior (Aderson and Gerbing, 1988). The above results suggest that the data is suitable for conducting path analysis using SEM.

\subsection{Analytical Tools}

This paper is to test the mediating role of legitimacy on procativeness and growth performance. Considering that the ISO certification is the single indicator for legitimacy, and some other control variables would not strictly conform to the normal distribution, we aim to take the advantages of the LISREL SEM and partial least square (PLS) and choose the most suitable method for our analysis. The methodology literature shows that the SEM model test has two popular methods: one is the linear structural relationship model that is LISREL structural equation modeling. Its advantage is that it can give exact evaluation on parameters such as the path coefficient of model and also give the fit index of the model at the same time. Theoretically, LISREL SEM defaults maximum likelihood estimate (ML), which requires the variables to be in multivariate normal distribution. However, much research finds that in most cases, variables do not conform to the normal distribution. As a result, it is reasonable to use maximum likelihood estimate (Hu, Bentler and Kano, 1992; Hau, Wen, and Cheng, 2004). 
Since our paper is to evaluate the path parameters exactly, it is more proper to choose LISREL model. Besides, our data involves a large sample. It is therefore more reliable to use LISREL maximum likelihood estimate (Hau et al., 2004). To make the model identified, for the single indicator, the factor's loading is fixed as 1 and the measuring error as 0 in LISREL analysis (Hau et al., 2004). To double check the reliability and credibility, this paper also uses the PLS Graph 3.0 and conduct the same analyses, the result of which has no significant difference from that of LISREL 8.7 path parameters test.

\section{Results}

\subsection{ANOVA Test: Is ISO Certification for Legitimacy Seeking?}

To examine whether the ISO certification has significant influence on the firm growth performance as well as the quality system, we conduct an ANOVA test with ISO certification as the grouping variable. The results show that the enterprises that have or have no ISO certification have significant difference on the three indicators of growth performance $(P<0.001)$, yet have no significant difference on the quality guarantee indicators - product quality stability and normative management $(P>0.10)$ (as shown in Table 4$)$. These results provide preliminary support to $\mathrm{H} 2 \mathrm{a}$ and $\mathrm{H} 2 \mathrm{~b}$.

Table 4 ANOVA Test on Five Key Factors across Two Groups (those with ISO Certification and those without)

\begin{tabular}{|c|c|c|c|c|c|}
\hline & Sum of squares & d.f. & Mean square & $F$ & Sig. \\
\hline \multirow{3}{*}{ Sales growth } & 15.612 & 1 & & \multirow{3}{*}{14.434} & \multirow{3}{*}{0.000} \\
\hline & 443.463 & 410 & 15.612 & & \\
\hline & 459.075 & 411 & & & \\
\hline \multirow{2}{*}{ Pre-tax profit growth } & 24.671 & 1 & 24.671 & \multirow{2}{*}{23.849} & \multirow{2}{*}{0.000} \\
\hline & 417.911 & 404 & 1.034 & & \\
\hline \multirow{3}{*}{ Market share } & 27.345 & 1 & 27345 & \multirow{3}{*}{23.432} & \multirow{3}{*}{0.000} \\
\hline & 471.473 & 404 & $\begin{array}{r}27.345 \\
1167\end{array}$ & & \\
\hline & 498.818 & 405 & 1.167 & & \\
\hline \multirow{3}{*}{ Product quality stability } & 0.460 & 1 & & \multirow{3}{*}{0.428} & \multirow{3}{*}{0.513} \\
\hline & 461.540 & 429 & .400 & & \\
\hline & 462.000 & 430 & & & \\
\hline \multirow{3}{*}{ Normative management } & 1.389 & 1 & & \multirow{3}{*}{1.359} & \multirow{3}{*}{0.24} \\
\hline & 447.802 & 438 & $\begin{array}{l}1.389 \\
1.027\end{array}$ & & \\
\hline & 449.191 & 439 & 1.022 & & \\
\hline
\end{tabular}

\subsection{Measurement Model}

The loading and significance test of the latent variables in SEM shows that the loading of all the latent variables is higher than the acceptable level 0.5 and $T$ is higher than the significance level of 1.96 . 
The correlation analysis on proactiveness, legitimacy and firm growth performance shows that both proactiveness and legitimacy have significant positive correlations with firm growth performance $(r=0.25, p<0.01 ; r=0.24$, $p<0.01)$. And proactiveness has a significant positive correlation with legitimacy $(r=0.21, p<0.01)$.

\subsection{Model Test}

There are two kinds of mediating model, one is a full mediation and the other is partial mediation (Baron and Kenny, 1986). According to the mediation test procedure of Baron and Kenny (1986) and Judd and Kenny (1981), the first step is to test whether the mediating variable (legitimacy), independent variable (proactiveness) and dependent variable (firm growth performance) are mutually correlated. When all of them are correlated, the second step test is taken, that is, to see whether the relationship between the independent variable (proactiveness) and the dependent variable (firm growth performance) will disappear when the mediator (legitimacy) is added into the relationship between proactiveness and firm growth performance. When the relationship does not disappear completely, the mediating variable plays a partial mediating role. As mentioned above, the three variables are correlated. Therefore, we move to the second step test.

Five possible nested models are derived: three non-mediation models, one partial-mediation model and one full-mediation model and are compared by LISREL8.7. The main comparing indicators for the five models are shown in Table 5. The fit indexes for all the five models are fine: the ratio of $\chi^{2}$ to $\mathrm{df}$ is

Table 5 Comparison among Five Nested Models

\begin{tabular}{|c|c|c|c|c|c|c|c|c|}
\hline Construct model & $\chi^{2}$ & $d f$ & $\Delta \chi^{2}$ & $\Delta d f$ & RMSEA & NNFI & $\mathrm{CFI}$ & GFI \\
\hline $\begin{array}{l}\text { 1.Full mediation: } \mathrm{PR} \rightarrow \mathrm{LE} \rightarrow \\
\text { GR }\end{array}$ & 184.19 & 117 & 5.12 & 1 & 0.042 & 0.96 & 0.97 & 0.94 \\
\hline $\begin{array}{l}\text { 2.Partial mediation: } \mathrm{PR} \rightarrow \mathrm{LE} \\
\rightarrow \mathrm{GR} \& \mathrm{PR} \rightarrow \mathrm{GR}\end{array}$ & 179.07 & 116 & 9.09 & 5 & 0.041 & 0.96 & 0.97 & 0.94 \\
\hline $\begin{array}{l}\text { 3.No mediation: } \mathrm{PR} \rightarrow \mathrm{GR} \& \\
\mathrm{LE} \rightarrow \mathrm{GR}\end{array}$ & 169.98 & 111 & & & 0.040 & 0.96 & 0.97 & 0.95 \\
\hline $\begin{array}{l}\text { 4. No mediation: } \mathrm{PR} \rightarrow \mathrm{LE} \& \\
\mathrm{PR} \rightarrow \mathrm{GR}\end{array}$ & 188.55 & 117 & 11.08 & 5 & 0.043 & 0.95 & 0.96 & 0.94 \\
\hline 5. No mediation: $\mathrm{PR} \rightarrow \mathrm{GR}$ & 177.47 & 112 & & & 0.042 & 0.96 & 0.97 & 0.94 \\
\hline
\end{tabular}

Note: PR means proactiveness, LE means legitimacy, GR means growth performance.

Model 4 in comparison with Model 5: $\Delta d f=5, \Delta \chi^{2}=11.08$, the critical value of $\chi^{2}$ is 15.09 when $d f=5$, and $\alpha=0.01$. It is evident that $\Delta \chi^{2}=11.08<15.09$. Therefore, Model 4 is better than Model 5.

Model 1 in comparison with Model 4: $d f$ is both 117; but $\chi^{2}$ of model 1 is smaller; so Model 1 is simpler. Therefore, the best model is among Model 1, 2, and 3 .

Model 2 compared to Model 3: $\Delta d f=5, \Delta \chi^{2}=9.09$, smaller than the critical value of $\chi^{2}$ which is 15.09 when $d f=5, \alpha=0.01$. Therefore, Model 2 is better than Model 3 .

Model 1 compared to Model 2: There is no significant difference between Model 1 and 2. 
smaller than 3; RMSEA smaller than 0.08, NNFI, CFI, GFI bigger than 0.9. According to model comparison principle recommended by Hau et al. (2004): the comparison between $\Delta \chi^{2}$ and $\Delta d f$ depends on the corresponding change of $\Delta \chi^{2}$ and $\Delta d f$. Only if the degree of freedom is increased by $\Delta d f$, the Chi-square increasing $\left(\Delta \chi^{2}\right)$ is less than the critical value of $\chi^{2}$ when the degree of freedom is $\Delta d f$, and $\alpha=0.01$, then the simplified model is better. Based on these principles, we made the following comparisons:

The partial mediation model based on Model 2 is shown in Fig. 1.

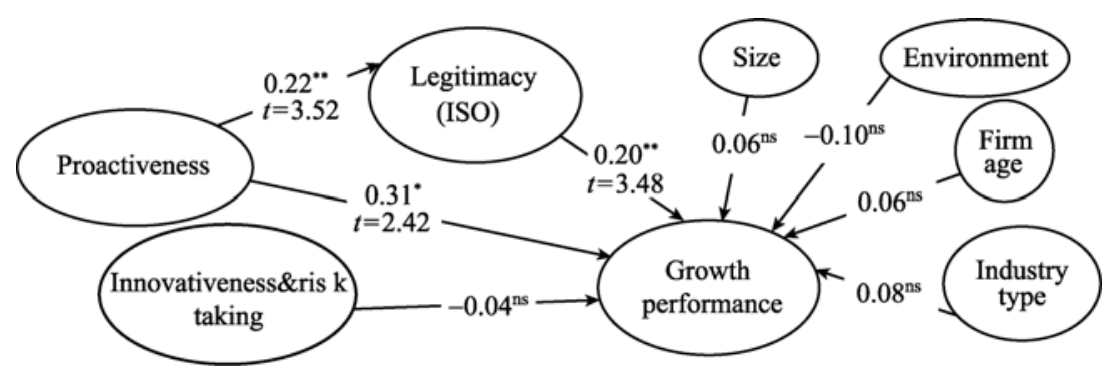

Fig. 1 Partial Mediation Model

According to Baron and Kenny's (1986) mediation test procedure, it depends on whether the direct effect of proactiveness and growth performance disappear to choose the better model between Model 1 and 2. See Table 5 and Fig. 1, for Model 1, without the mediation role, the standard path coefficient of proactiveness and growth performance is $0.52(t=3.59, p<0.01)$; for Model 2, with mediation role, the standard path coefficient of proactiveness and growth performance is $0.31(t=2.42, p<0.05)$. The path coefficient difference of the two models is 0.21 , which means the mediation effect of legitimacy indeed exists. However, the direct effect of proactiveness and growth performance still exists obviously. Therefore, this paper accepts the Model 2 that legitimacy plays a partial mediating role in proactiveness and firm growth performance: the standard path coefficient from proactiveness to legitimacy is $0.22(t=3.52, p<$ 0.01 ); the standard path coefficient from legitimacy to firm growth performance is $0.20(t=3.48 ; p<0.01)$. These results support $\mathrm{H} 3$, and further support $\mathrm{H} 1$ and $\mathrm{H} 2 \mathrm{a}$.

\section{Discussion and Conclusion}

\subsection{Theoretical Contributions}

The institutionalism suggests that companies have an isomorphism pressure from social system including rules, norms and cognition etc., and they need to 
ceremonially accept these institutions and adopt symbolic action to gain legitimacy regardless of whether this action is being implemented (Meyer and Rowan, 1977; Zucker, 1983). This paper tests the validity of this legitimacy perspective in the context of emerging economy of China. Our findings suggest that ISO certification plays a legitimizing role. In other words, with the acquisition of ISO, SMEs legitimize proactive action to realize the first-mover advantage and produce better performance. This research highlights the critical role of legitimating strategy during the economic transition of China. Besides, we also find that SMEs' acquisition of ISO does not help improve the enterprises' quality guarantee capability, illuminating that SMEs seek ISO certification just for playing the legitimizing role rather than relying on it to enhance quality standard.

This paper makes two major contributions to the current literature. First, it tested the positive role of proactiveness on firm performance in the context of China's emerging economy. Different from the previous literature which regards EO as a single construct with multidimensions (Dess and Lumpkin, 2005), this research followed Dess and Lumpkin (2005) by, focusing on a single dimension of EO: the proactiveness and examined the important function of proactiveness to SEMs' growth in the context of China. A second contribution of this paper lies in that it conceptualized and tested the mediating effect of legitimacy as the partial mediator between proactiveness and SEMs' growth performance. In so doing, it extends the current research on the direct link between EO constructs and firm performance, and reveals legitimacy as a transforming mechanism from proactiveness to firm growth performance during the entrepreneurship process.

Although institutional theory underlies that facing with institution isomorphism pressure and legitimacy threshold, enterprises can improve their survival and growing opportunities by enhancing cognitive legitimacy of customers, government, suppliers and other stakeholders through proper legitimizing strategy and methods (Zucker, 1983; DiMaggio and Powell, 1983; 1991; Zimmerman and Zeitz, 2002; Scott, 1995), institutionalists often emphasize too much on legitimacy while neglect to examine the positive effect of proactiveness on firm performance: a paradox to the institutional theory. A possible explanation might be that proactive enterprises tend to face harsher legitimacy constraints. This article combines the two streams of literature, the EO literature and the legitimacy perspective, and tests the mediation function of legitimacy in the process of proactiveness transforming into firm performance. It helps establish the connection between legitimacy and EO theory and to some extent helps avoid the cognition bias resulting from any single theoretical perspective.

The important difference of our work from the previous EO literature is that the former research is confined to entrepreneurship strategy level and focuses on 
the relationship among proactiveness, first-mover advantage and organization performance (e.g., Miller and Friesen, 1983; Lumpkin and Dess, 1996; Lieberman and Montgomery, 1998; Lieberman and Montgomery, 1988). Our research suggests that the first-movers may face legitimacy constraints (Lieberman and Montgomery, 1998; 1988); however, managing the legitimacy or adopting legitimacy strategy can help firms successfully achieve the first-mover benefits.

\subsection{Managerial Implications}

The EO research emphasizes the importance of proactiveness to firm growth, but is unable to effectively explain why some first-movers can not gain first-mover advantage even after they have created innovative products. This study extends previous explanation and suggests that first-movers need to take legitimation action to strengthen the stakeholders' approval to their new products, services or behaviors so as to fully transform proactiveness into first-mover advantage and higher firm growth performance. However, usually, the direct effect on firm growth brought by proactiveness is not enough to support firm growth. SMEs shall not only expect a rapid growth by having more innovative actions, but also need to overcome the legitimacy obstacle by taking legitimation action in order to ensure that the proactive innovations are taken into positive effect (as shown in Fig. 2).

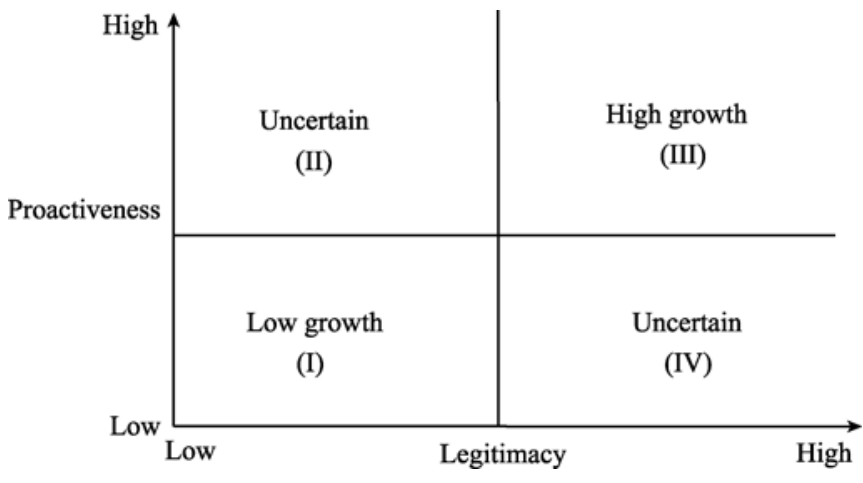

Fig. 2 Two-Dimension Growth Model of SMEs

Specifically, our research has the following implications for enterprise managers. Enterprises with both high proactiveness and legitimacy will gain high growth performance. Different from the previous single cognition that proactiveness is positively related to firm performance, in certain context (Miller and Friesen, 1983; Lumpkin and Dess, 1996), first-movers may face broader market opportunity by having the first-mover advantage but also encounter more 
legitimacy problems. Therefore, first-movers need to convey reliable and credible information to stakeholders about their product, service or action (e.g., obtaining ISO certification) to eliminate the uncertain misgivings from customers and convert proactive products or service into first-mover advantage. However, not every enterprise attempting to improve legitimacy succeeds. Enterprises with high proactiveness and legitimacy are more likely to gain better growth performance either through the direct effect of proactiveness or the mediating effect of legitimacy on firm performance (see quadrant III in Fig. 2).

As shown in Fig. 2, the growth performance of those enterprises with high proactiveness and low legitimacy are not certain in the long-term. First-movers enter into a market firstly and might gain the growth opportunity and the monopoly profit in the short-time. If the first-movers are luckily located in a seller's market, proactiveness often means better profit, such as the first generation of entrepreneurs at the beginning of China's reform and opening of the market. But for firms in the buyer's market, in the long term, the first-movers with low legitimacy cannot maintain the growth brought by proactiveness for long and their legitimacy bottleneck will become increasingly serious. For example, most Chinese enterprises are short of famous brands which are highly approved by society reflect the fact that the society's approval to these enterprises is not high (hence, they have low legitimacy). Lacking a long-term cognitive legitimacy such as the brand cognition has a negative influence on these enterprises' long-term growth, and leads them to be vulnerable to crisis (see quadrant II in Fig. 2).

The growth performance of those enterprises with high legitimacy and low proactiveness are not certain too. Different from the single viewpoint of the institutionalism that legitimacy is positively related to firm growth performance (Zimmerman and Zeitz, 2002), our legitimacy mediation model implies that enterprises with high legitimacy might maintain survival or growth depending on a reasonable exploitation of the existing products, service or process. However, this kind of growth is difficult to sustain. In the long run, firm performance might stay at a low level, and firms face the risk of being replaced by those having new products due to a lack of proactiveness (see quadrant IV in Fig. 2).

Enterprises low in both proactiveness and legitimacy will gain low performance. The partial mediation model further suggests that, compared to first-movers, followers might often face the increasingly intensive competition in the market. The chance for monopoly profit is small and the growth space for enterprises is decreasing. Under this situation, if these enterprises do not pay attention to enhance legitimacy, the accepted level of their existing products and service might be reduced, or even be replaced by the products of later first-movers. Therefore, the performance of those enterprises with low proactiveness and legitimacy are the worst (see quadrant I in Fig. 2). 


\subsection{Limitations and Future Research Directions}

The first limitation of this paper is that we use ISO certification as the single indicator to measure legitimacy. However, to date, there is no unanimously approved measuring scale for legitimacy in the field of institutional research (Ruef and Scott, 1998). Strictly speaking, ISO is a more representative scale for measuring normative legitimacy rather than regulative legitimacy and cognitive legitimacy (ISO certification through enterprise advertising may measure part of the cognitive legitimacy). To enhance the representation of legitimacy measure scale, we still need to develop multiple legitimacy scales.

The second limitation is that we find that legitimacy plays a partial mediating role between proactiveness and firm growth performance. However, both the practical and theory fields may pay more attention to the question: under which condition that the direct function of proactiveness is greater and under what condition that the mediation affect of legitimacy is more prominent. Following this question, more questions remain unanswered. First, whether or not the mediation model between proactiveness and performance will change when the difference on product attributes is considered. Some types of products might face lower legitimacy constraints and the proactiveness constitutes the main source for growth performance. While some products might face stronger legitimacy constraints, and enhancing legitimacy might contribute much more to performance. Second, whether or not the mediating role of legitimacy will change when enterprise life cycle is considered. New ventures usually face higher legitimacy constraints than the existing companies; therefore, new ventures need to realize the first-mover advantage by legitimation action. Third, what is the contingent influence of technology continuity of the products on the mediation model? In the industry where the technology is not continuous, it is difficult for the companies with high proactiveness to gain first-mover advantage; the later comers can enter into the market taking the advantage of the technology's discontinuity, and become a "free rider" of early legitimizing actions (Lieberman and Montgomery, 1988).

The third limitation lies in the causality among the key examined factors. Theoretically, we put forward a mediating model with the factor of proactiveness as the independent predictor and legitimation as mediator; however, we can not deny that good firm performance stimulates enterprises to apply for ISO certification. This limitation calls for more dynamic approach to test the interrelationships among proactiveness, legitimacy and growth. Future research can collect panel data. By using of the multiple data points, we can test the stability of the model in a continuous time series. At the same time, the data can analyze the performance change before and after ISO certification in order to test 
the causal ambiguity.

Acknowledgments This work is supported by the Key Program of National Natural Science Foundation of China (No. 70732004), General Program of National Natural Science Foundation of China (No. 70672107), Young Scientists Fund of National Natural Science Foundation of China (No. 70902080), and Humanities and Social Sciences Youth Program of the Ministry of Education of China (No. 07JC630028). Special thanks go to Mr. Dahui Li for his good suggestions and assistance in research method.

\section{References}

Aderson J C, Gerbing D W (1988). Structural equation modeling in practice: A review and recommended two step approach. Psychological Bulletin, 103(3): 411-423

Ashforth B E, Gibbs B W (1990). The double-edge of organizational legitimation. Organization Science, 1(2): 177-194

Baker W E, Sinkula J M (2009). The complementary effects of market orientation and entrepreneurial orientation on profitability in small businesses. Journal of Small Business Management, 47(4): 443-464

Baron R M, Kenny D A (1986). The moderator mediator variable distinction in social psychological research: Conceptual, strategic, and statistical considerations. Journal of Personality and Social Psychology, 51(6): 173-182

Baum J R, Locke E A, Smith K G (2001). A multidimensional model of venture growth. The Academy of Management Journal, 44(2): 292-303

Boiral O (2003). ISO 9000: Outside the iron cage. Organization Science, 14(6): 720-737

Bourgeois L J (1980). Strategy and environment: A conceptual integration. Academy of Management Review, 5: 25-39

Chin W, Newsted P (1999). Structural equation modeling analysis with small sampling using partial least squares, In: Rick Hoyle (ed.), Statistical Strategies for Small Sample Research. CA: Sage Publications, 307-341

Covin J G, Slevin D P (1989). Strategic management of small firms in hostile and benign environments. Strategic Management Journal, 10(1): 75-87

Covin J G, Slevin D P (1991). A conceptual model of entrepreneurship as firm behavior. Entrepreneurship: Theory and Practice, 16(1): 7-24

Deephouse D L (1996). Does isomorphism legitimate? The Academy of Management Journal, 39(4): 1024-1039

Delmar F, Shane S (2004). Legitimating first: Organizing activities and the survival of new ventures. Journal of Business Venturing, 19: 385-410

Dess G, Lumpkin T (2005). The role of entrepreneurial orientation in stimulating effective corporate entrepreneurship. Academy of Management Executive, 19(1): 147-156

Dess G, Lumpkin T, Covin J G (1997). Entrepreneurial strategy making and firm performance: Tests of contingency and configurational models. Strategic Management Journal, 18: 677-695

DiMaggio P J, Powell W (1983). The iron cage revisited: Institutional isomorphism and collective rationality in organizational fields. American Sociological Review, 48(2): $147-160$

DiMaggio P J, Powell W (1991). Introduction to the New Institutionalism in Organization Studies. Chicago: The University of Chicago Press 
Dowling J, Pfeffer J (1975). Organizational legitimacy: Social values and organizational behavior. The Pacific Sociological Review, 18(1): 122-136

Gefen D, Straub D, Boudreau M (2000). Structural equation modeling and regression: Guidelines for research practice. Communications of the Association for Information Systems, 4(7): 1-77

Hargadon A B, Douglas Y (2001). When innovations meet institutions: Edison and the design of the electric light. Administrative of Science Quarterly, 46: 476-501

Haunschild P R, Miner A S (1997). Modes of interorganizational imitation: The effects of outcome salience and uncertainty. Administrative Science Quarterly, 42(3): 472-500

Hu L, Bentler P M, Kano Y (1992). Can test statistics in covariance structure analysis be trusted? Psychological Bulletin, 112: 351-362

Judd C M, Kenny D A (1981). Process analysis: Estimating mediation in treatment evaluations. Evaluation Review, 5(5): 602-619

Li Y, Zhao Y B, Tan J, Liu Y (2008). Moderating effects of entrepreneurial orientation on market orientation-performance linkage: Evidence from Chinese small firms. Journal of Small Business Management, 46(1): 113-133

Lieberman M B, Montgomery D B (1988). First-mover advantages. Strategic Management Journal, 9: 41-58

Lieberman M B, Montgomery D B (1998). First-mover (dis)advantages: Retrospective and link with the resource-based view. Strategic Management Journal, 19(12): 1111-1125

Lumpkin T, Dess G (1996). Clarifying the entrepreneurial orientation construct and linking it to performance. The Academy of Management Review, 21(1): 135-172

Maurer J G (1971). Readings in Organizational Theory: Open System Approaches. New York: Random House

Meyer J, Rowan B (1977). Institutional organizations: Formal structure as myth and ceremony. The American Journal of Sociology, 83(2): 340-363

Miller D (1983). The correlates of entrepreneurship in three types of firms. Management Science, 29(7): 770-791

Miller D, Friesen P H (1983). Strategy-making and environment: The third link. Strategic Management Journal, 4(3): 221-235

Nadkarni S, Narayanan V K (2007). Strategic schemas, strategic flexibility and firm performance: The moderating role of industry clock speed. Strategic Management Journal, 28: $243-270$

Oliver C (1991). Strategic responses to institutional processes. Academy of Management Review, 16(1): 145-179

Parsons T (1960). Structure and Process in Modern Societies. Glencoe, IL: Free Press

Pfeffer J, Salancik G R (1978). The External Control of Organizations: A Resource Dependence Perspective. New York: Harper \& Row

Podsakoff P, Organ D (1986). Self reports in organizational leader reward and punishment behavior and research: Problems and prospects. Journal of Management, 12(4): 531-544

Ruef M, Scott W R (1998). A multidimensional model of organizational legitimacy: Hospital survival in changing institutional environments. Administrative Science Quarterly, 43(4): 877-904

Scott W R (1995). Institutions and Organizations. Thousand Oaks, CA: Sage

Shepherd D A, Zacharkis A (2003). A new venture's cognitive legitimacy: An assessment by customer. Journal of Small Business Management, 41(2): 148-167

Singh J V, Tucker D J, House R J (1986). Organizational legitimacy and the liability of newness. Administrative Science Quarterly, 31(2): 171-193 
Stam W, Elfring T (2008). Entrepreneurial orientation and new venture performance: The moderating role of intra-and extraindustry social capital. Academy of Management Journal, 51(1): 97-111

Stinchcombe A L (1965). Organizations and Social Structure. In: James G March (ed.), Handbook of Organizations. Chicago: Rand-McNally, 142-193

Stuart T, Hoang H, Hybels R (1999). Inter-organizational endorsements and the performance of entrepreneurial ventures. Administrative Science Quarterly, 44(2): 315-349

Suchman M C (1995). Managing legitimacy: Strategic and institutional approaches. Academy of Management Review, 20(3): 571-610

Teece D J (1986). Profiting from technological innovation: Implications for integration, collaboration, licensing and public policy. Research Policy, 15: 285-305

Terreberry S (1968). The evolution of organizational environments. Administrative Science Quarterly, 12: 590-613

Tornikoski E T, Newbert S L (2007). Exploring the determinants of organizational emergence: A legitimacy perspective. Journal of Business Venturing, 22: 311-335

Weber M (1958). The Protestant Ethic and the Spirit of Capitalism. New York: Scribners

Weber M (1968). Economy and Society: An Interpretive Sociology, Guenther Roth and Claus Wittich (eds.). New York: Bedminister Press

Wiklund J, Shepherd D (2003). Knowledge-based resources, entrepreneurial orientation, and the performance of small and medium-sized businesses. Strategic Management Journal, 24: $1307-1314$

Zimmerman M A, Zeitz G J (2002). Beyond survival: Achieving new venture growth by building legitimacy. Academy of Management Review, 27(3): 414-431

Zott C, Huy Q N (2007). How entrepreneurs use symbolic management to acquire resources. Administrative Science Quarterly, 52(1): 70-105

Zucker L G (1983). Organizations as institutions. In: Research in the Sociology of Organizations, vol. 2, Bacharach S B (eds.). Greenwich, CT: JAI Press, 1-42

侯杰泰, 温忠麟, 成子娟 (Hau Kit-Tai, Wen Zhonglin, Cheng Zijuan) (2004). 结构方程模 型及其应用 (Structural Equation Model and Its Applications). 北京: 教育科学出版社

李乾文 (Li Qianwen) (2007). 公司创业导向的差异分析一一基于环渤海地区企业所有权 差异的实证研究 (Difference analysis of corporate entrepreneurial orientation: Empirical research based on enterprise ownership difference of Bohai sea region). 科学学研究, 25(4): $708-710$ 